\title{
Students as a subject of the e-learning environment
}

\section{Los estudiantes como asignatura del entorno de e-learning}

\author{
Nadija Figol \\ figol_nadija@ukr.net \\ https://orcid.org/0000-0002-2503-7243 \\ National Technical University of Ukraine "Igor Sikorsky Kyiv Polytechnic Institute". \\ Vasyl Teremko \\ v.teremko@ukr.net \\ https://orcid.org/0000-0002-9045-7674 \\ Taras Shevchenko National University of Kyiv, Ukraine. \\ Iryna Pobidash \\ nazarira@email.ua \\ https://orcid.org/0000-0001-9876-2203 \\ National Technical University of Ukraine "Igor Sikorsky Kyiv Polytechnic Institute". \\ Aelita Lytvyn \\ a-elita@ukr.net \\ https://orcid.org/0000-0003-3897-6175 \\ National Technical University of Ukraine "Igor Sikorsky Kyiv Polytechnic Institute" \\ Tetiana Skorokhod \\ skorokhod.tetiana@gmail.com \\ https://orcid.org/0000-0003-1585-700X \\ National Technical University of Ukraine "Igor Sikorsky Kyiv Polytechnic Institute". \\ Ruslan Trishchuk \\ 3182233@ukr.net \\ https://orcid.org/0000-0002-6286-8345 \\ National Technical University of Ukraine "Igor Sikorsky Kyiv Polytechnic Institute".
}

Recibido: $26 / 08 / 21$

Aceptado: $26 / 10 / 21$

\section{Abstract}

The article is devoted to the subjective role of the student community in the e-learning environment. The basic personal attributes of a modern student required for successful learning in the electronic learning environment were defined, including proactive attitude, motivation, creativity, independence, persistence. The tasks that should be overcome by students to achieve the goal of successful learning were outlined as follows: to take personal responsibility for the process and the final result of learning, to increase their motivation and interest in a positive outcome, to be able to develop communication with 
other students and the lecturer, to associate the acquired theoretical knowledge with their experience and practical skills. Distant learners were outlined to face a variety of challenges from technical issues and lack of guidance materials to communication difficulties, which are just as important.

The conclusion to be drawn is that the functions and competencies of both students and teachers are changing in the e-learning environment. Communication moves to a different level and starts to be from a peer to peer perspective. The e-learning environment requires students to be more self-organized, goal-oriented, self-conscious in the process of education, to realize the purpose of their cognitive activity, to be inquisitive and passionate.

Key words: electronic learning environment, communication, students, competencies.

\section{Resumen}

El artículo está dedicado al papel subjetivo de la comunidad de estudiantes en el entorno del e-learning. Se definieron los atributos personales básicos de un estudiante moderno requeridos para un aprendizaje exitoso en el entorno de aprendizaje electrónico, incluida la actitud proactiva, la motivación, la creatividad, la independencia y la perseverancia. Las tareas que deben superar los estudiantes para lograr el objetivo de un aprendizaje exitoso se delinearon de la siguiente manera: asumir la responsabilidad personal del proceso y el resultado final del aprendizaje, aumentar su motivación e interés en un resultado positivo, poder desarrollar comunicación con otros estudiantes y con el profesor, para asociar los conocimientos teóricos adquiridos con su experiencia y habilidades prácticas. Se describió a los estudiantes a distancia para enfrentar una variedad de desafíos, desde problemas técnicos y falta de materiales de orientación hasta dificultades de comunicación, que son igualmente importantes.

La conclusión a extraer es que las funciones y competencias tanto de estudiantes como de profesores están cambiando en el entorno del e-learning. La comunicación se mueve a un nivel diferente y comienza a ser desde una perspectiva de igual a igual. El entorno de e-learning requiere que los estudiantes sean más autoorganizados, orientados a objetivos, conscientes de sí mismos en el proceso de educación, que se den cuenta del propósito de su actividad cognitiva, que sean curiosos y apasionados.

Palabras clave: entorno de aprendizaje electrónico, comunicación, estudiantes, competencias.

\section{Introduction}

In the modern era of active informatization of society, the spread of distance learning has increased interest in learning in an e-learning environment. Distance learning was especially relevant during the Kovid 19 pandemic, when most educational institutions in many countries were forced to switch to distance learning. During such training, both methods, forms of educational activities and the role of subjects in electronic 
communication change, so it is important to find out new competencies and functions that should be acquired by its main subject - students, which determines the relevance of our study.

Therefore, the aim of the article is to identify new competencies of students in the e-learning environment, its functions in the era of global informatization of society and the transition to online learning. After all, the success of communication in the form of distance learning will depend on the acquisition of these new competencies, which will testify to the success of educational activities in general, and hence the achievement of the ultimate goal - the acquisition of new knowledge. Solving this problem will make it possible to identify new competencies of students needed for distance learning, which will help to form these new competencies in them for successful further study, will make communication in the e-learning environment productive and successful. To date, researchers have mainly studied the peculiarities of students' perception of e-learning publications, the effect of these e-learning publications on students and their cognitive activity, but the subjective role of students as a subject of communication in e-learning environment researchers did not touch, so we were interested to focus on this issue and highlight the competency characteristics of students that will help in educational and cognitive activities. We accept as a hypothesis the statement that in the period of distance learning students must acquire new competency characteristics for successful communication in the e-learning environment.

\section{Methodology}

The methods used in the study include general scientific methods of analysis and synthesis, which allowed to identify specific characteristics of modern students, to establish its inherent competencies, to determine the necessary advantages in the e-learning environment.

A descriptive method, in particular a typology method focused on finding a stable feature and property of an object, was also used in the study. This method allowed to determine the characteristics of modern students in the e-learning environment. The method of typological analysis allowed to analyze and compare the effectiveness and efficiency of the latest competencies of modern students, identifying general trends and prospects for development.

The article uses Case Study - a method of qualitative research in the social sciences, which consists in the study of a single social object (situation, event) in order to understand a wider class of similar cases (class of events). In the context of this article, it is a study of the characteristics of students in order to generalize the phenomenon of this phenomenon in the era of informatization of society. 


\section{Literature review}

The e-learning environment and distance education are currently being actively studied by both foreign and Ukrainian scientists.

Among the domestic research should be noted the following aspects: interactive technologies of adult learning (Sysoeva, 2011), the theory and practice of blended learning (Kukharenko, Berezenskaya, \& all, 2016), Distance learning (Kukharenko, \& Sirotenko, 2016), the formation of critical student thinking (Oliynyk, 2016), gamification in blended learning (Stolyarevska, 2016), features and possibilities of using blended learning (Rybalko, \& Syrotenko, 2016), etc.

Among foreign studies should be noted works: Christopher Pappas. "The best statistics and facts of e-learning for 2015 that you need to know" (Pappas, 2015); Bernie Trilling "Towards Learning Societies and Global Challenges of ICT Learning" (Trilling, 2007); Sharon Boller "E-learning trends that disappoint, impress or prolong in 2014" (Boller, 2014); Catherine Davis "The most popular trends and prospects for educational design in 2014" (Davis, 2014); Justin Ferriman "The future of e-learning in 2014" (Ferriman, 2014); Lewis Carr "10 predicted e-learning trends for 2014/15" (Carr, 2014).

\section{Results and Discussion}

The electronic learning environment has modified the communicative status and recipients of information, namely pupils and students, who turn from passive participants into active co-creators of the communication process. This is facilitated by the availability of interactive elements in the electronic textbooks, when the recipient is able, first, to choose an acceptable level of learning the material, and secondly, to share their wishes with the authors and developers. At times, pupils and students are also involved in creating additional supporting materials, such as relevant cases, tasks, exercises, gamification elements which significantly improve the efficiency of the learning process due to their interest and so-called involvement in the process. The pro-active role of the pupil or student in the communication process in the electronic learning environment involves acquiring new skills and performing unusual functions.

First and foremost, the pro-active attitude should be singled out as one of the essential skills. The pupil or student should first of all demonstrate their interest in the learning process, be active instead of being passive in absorbing dogmas, truths, and knowledge, which may become obsolete over time.

In addition, the modern student should be aimed at obtaining a positive effect from learning, and therefore be motivated to the educational process. The prerequisites of motivation can be established both in the educational institution and, above all, in the family. 
Nowadays, an essential competence for students is their imagination and creativity, which will help them to apply non-standard solutions and go beyond clearly defined boundaries if required. A student in the electronic learning environment actually becomes the creator of his cognitive reality, being able to move to other information resources via hyperlinks, finding additional interesting information on other platforms. For this reason, the creative component, which will help both solve non-typical challenges and construct the electronic reality in the e-learning environment, becomes such a necessary competence for the modern student. If the student of the previous century could be characterized as a good performer who was diligently absorbing the amount of knowledge selected for him, the modern student can be called a creator who is developing his own electronic learning environment.

A summarized profile of a modern student implies the existence of such communicative competencies as independence, persistence in acquiring new knowledge, sociability, courage in decision-making and the ability to organize and manage time that is known as time-management.

Time management is currently a very significant communicative competence, since learning in the electronic environment, in a distance mode, on the one hand, provides favorable conditions and saves time, as a student becomes independent and free to choose the time and space boundaries of his education. On the other hand, it is a huge challenge for individuals who are unable to organize their free time and establish an appropriate schedule for absorbing and processing new information. Therefore, the learning process in the e-learning environment is freer and more democratic, but not everyone can self-organize and cope with the given freedom of choice. Thus, the next equally important competence for the modern student is self-organization that determines a significant percentage of success in learning.

Important communicative features of the modern student include independence and persistence in acquiring knowledge, as time and space limits for obtaining new knowledge disappear or get erased: there is no need to go to the classroom at a strictly defined time, and so on. After getting specific guidelines in the form of video-conferences, handouts - presentations, the student remains alone, and it is only up to him, to his independence, perseverance and motivation, whether he can efficiently use the obtained materials, what he can find and apply independently to solve complex non-standard problems, in other words there is a basis (received from the tutor), while the entire superstructure (acquired knowledge, skills) depends on each individual student, which will actually form his personal electronic learning environment.

Modern educators have created a summarized profile of "distance learners who are successful in studying: they are proactive in creating new projects; they are married; they are not afraid of difficulties; their desire for success in learning outweighs their lack of experience; they do not require support for difficult tasks and do not consider it important to discuss the term paper with other students; they have a high educational level; they consider themselves to be highly organized in time management; they 
strongly appreciate formal and informal learning for getting a degree; the female students achieve the most successful results" (Kucharenko, Berezenskaya, \& all, 2016).

The fundamental skill for the modern student should be the ability to learn: the ability to find the right information, to organize the material, to be self-organized and selfdisciplined, and all this cannot be achieved without a high degree of motivation, which we have focused on at the very beginning. That is why it is important to develop these competencies from childhood, and they will be useful later in life, because the wellknown saying "It is never too late to learn" is especially relevant in the period of globalization and informatization of society, as well as the rapid development of information technologies.

It's worth taking a closer look at the notion of "being able to learn" - that is, being able to search out, identify, and filter information above all. Obviously, the tutor, who is supposed to instill these skills in the students, learners-beginners, especially in the first years of their studies, comes to the fore here. Another no less important skill among the learning abilities is the competence to manage your time, because unlimited and uncontrolled access to information carries another threat of getting bogged down and carried away with the details, moving away from the main and essential things. An essential competence of the student in the information age is the ability to ask questions and not be afraid to communicate, because it determines whether the learning process goes in the proper direction, whether the student understands both the tasks and the received information.

The democratic style of communication in the electronic learning environment implies the ability of students to think critically. Over the past decade, higher and secondary educational institutions have introduced the corresponding subject called "Fundamentals of Critical Thinking", which is aimed at providing students with the skills to think independently, to call everything into question, to argue and prove their point of view. According to $E$. Polat, this type of thinking is a consistent, well-reasoned, goal-oriented cognitive process that is characterized by the desire to planning of mental activity, persistence and consistency in achieving the goal, self-correction (Polat, 2000). All these factors indicate the cognitive maturity of students, their understanding of the learning process, readiness and motivation to absorb new material that greatly depends on the attitudes and highly skilled work of the tutor.

Meanwhile, the information age and e-learning environment, in particular, put a number of requirements on the modern pupil or student. First of all, the modern recipient should have computer skills at a high level in order to easily use the software and electronic editions provided as part of distance learning. Secondly, it is necessary simply to have technical means, such as a laptop, tablet, smartphone, and access to the World Wide Web, since we cannot even talk about an informatized society and distance learning if we do not have technical support. In other words, another competence of a modern successful student can be described as the ability to use technical means at a high level. 
There is also the related ability to use the World Wide Web freely and safely, so many educational institutions at different levels provide courses like "Internet Security", "Web Safety", etc. After all, unlimited access to the Web imposes no less responsibility and can sometimes carry serious threats to the younger generation, which again should be guarded by the experienced tutor, who will steer the juvenile ardour and enthusiasm on the right course.

Another essential attribute of a modern student or pupil should be the ability to think critically, the ability to subject everything to a healthy criticism and analysis, since unlimited access to the Web makes it possible to find unfair resources and receive false information. The only way out of this situation is constant analysis and verification of information on several reliable sources that will prevent the distribution of fake information to students. In this regard, the role of the tutors is also indispensable, as they should provide the necessary literature, have an in-depth knowledge of the issue, and, if required, refute false facts.

In addition to the competencies that modern students should have in the e-learning environment, we should also take a look at the objective difficulties they may face. Communication in the e-learning environment should be organized at a high level, as it will influence the entire successful effect of learning. Certainly, the biggest communicative problems occur at the first stages of communication when it is necessary to establish the connection with the audience and set up the learning process itself. This can be achieved due to the organizational and managerial competences of the lecturer or tutor, who should clearly structure the course as regards both the presentation of information and the temporal and spatial plane. To prevent students from being confused and demotivated at the beginning of their studies, it is necessary to keep a constant dialogue in the chat, inform them in advance about all the organizational moments and meetings, clearly outline the procedure for further studying and communicating; it is also useful to make information sheets and schedules indicating what should be done and when it should be handed in.

An important point for successful and easy communication is the availability and publication of supporting methodological materials on the site, which students can refer to at a convenient time and repeat or renew the information they have received.

Another communication problem that students face during distance learning is a feedback from the lecturer, and since most of these students are learning at their offwork time, they want to get answers and assistance right away, when it is convenient for them. In this case, at the initial stage of studying there should be clearly specified time limits when it is possible to ask for help, as well as certain hours of consultations, and it is important to carry out some final conversations after each stage of communication. For the purpose of identifying misunderstandings, problem points, and discussing important issues, a skilled tutor can continue chatting during the learning period and in unlimited access. At the same time, students, especially at the initial stage, may be hesitant to ask questions or express their concerns, so the tutor should 
anticipate possible difficulties in a certain way and explain them in the methodological guidelines posted on the site.

Another significant problem in distance learning involves the technical difficulties that students face. In order to avoid them, the distance learning course should be well tested and organized with the least number of technical points difficult to pass, and it is also important that the tutor can immediately give explanations and help the students, so as not to demotivate them. This problem is particularly emphasized by educators $\mathrm{V}$. Kuharenko and others: "Lack of access to technical assistance brings about maximum inner tensions among students. Organizational issues related to feedback take the second place here. In terms of course content and the tutor's activities to ensure communication with all students, the feeling of confusion, anxiety, and frustration was the strongest when students did not receive prompt feedback from the tutor, found inconsistencies in the interpretation of online and email directions" (Kuharenko, Berezenskaya \& all 2016).

Distance learning has a number of challenges that students have to overcome in order to achieve the goal:

1. Taking personal responsibility. A strong motivation is required to complete a distance learning course, so tutors should enhance it by providing interactivity, namely feedback, that is, by establishing successful communication.

2. Increasing motivation. The student should realize the goals and objectives of learning, and the educator should determine the student's abilities and help make learning more motivating.

3. Maintaining and enhancing self-esteem. Distance learning students may have doubts about their abilities. The educator should boost self-esteem by giving feedback, commenting, explaining difficult points of tasks, i.e. by establishing successful communication.

4. Communicating with other students. Learning is the most efficient in a group when there is an opportunity to discuss tasks and share experiences. The tutor should encourage such contacts and joint solution of academic tasks.

5. Clarifying and realizing the level of knowledge. The students should be able to express what they are studying, explore their own electronic learning information environment, as it will change when new information is introduced. It is useful to submit a report to the tutor on the work done and the role of the learned material in the studying process.

6. Connecting acquired knowledge with one's own experience. It is necessary to take into account that personal backgrounds and attitudes are also important achievements of students. The tutor's role in distance learning is to help the students realize the value of their experiences and their importance in the further learning process. 
It can be claimed that the success of studying in the electronic learning environment will greatly depend on the successful interaction of all participants in the communication process. From the very beginning of communicative learning activity it is necessary to establish clear conditions, the rules of the game, to agree on the stages and ways of communication, so that students are informed when they can contact the tutor, in what form communication will occur, what communication links and systems will be applied, so that the recipient is not left helpless alone with his difficulties and does not lose interest in cognitive activity. It is also necessary to set clear time limits, deadlines for performing and handing in certain forms of control and assignments.

To sum up, students face a number of problems in the e-learning environment, including:

- Lack of clear methodological resources, guidelines for learning the material and performing tasks;

- Shortcomings of communication channels and conditions of interaction with the tutor;

- Communicative ignorance of all participants in the communication process;

- Failure of tutors to realize the need for constant communication with students;

- Lack of preparatory stage to mastering a distance learning course in the e-learning environment.

As you can see, most of these problems belong to the communication field and can be easily solved if there is enough awareness and willingness to eliminate them.

Let's discuss the ways and techniques for establishing successful communication for students in the e-learning environment. The first thing to do is to create communication channels that are convenient and available to students, and let them know about these channels. These can be online channels that take place during communication (webinar, zoom, etc.), i.e. chats, which are the most convenient and so-called instant channel of communication, which allows you to immediately put a question and quickly get an answer. In this case, it is necessary to determine the time frame when you can communicate in the chat (at the end of the presentation of theoretical material, after the lecture, etc.), so that questions are not left without answers and do not give the impression of being irrelevant.

Another equally efficient communication channels are email and social media (Telegram, Instagram, etc.), where important information about the start of the course, deadline for completing tasks, submitting forms of control, passing tests, etc., can be posted. By using these communication channels, students can ask questions and find out what they cannot understand. The tutor should be sympathetic to the fact that most distance learners will be studying in their off-work time, so they will learn in the evenings and at the weekend - and that is when they may have questions and require answers. However, the tutor cannot stay in front of a monitor or smartphone round the clock without days off, so for the purpose of comfortable communication it is worth setting 
clear time limits and so called personal boundaries, so that interaction was positive and brought pleasure to all participants of the communication process.

For effective communication, the form of delivering information plays an important role, so the skillful tutor should also pay special attention to it, because the mood and tone of the conversation greatly influence the results. In chatting and emailing, you should keep a good-natured, positive tone without dogmas or directives, so as to set the student up to perceive you as a person and information in general. The wording should be clear and unambiguous, so that the recipient could get a clear algorithm for action and not be distracted or confused. For example, the following organizational wording can be offered: "Read, please!", "Important information", "Algorithm of task performance", "Test evaluation", "System of assignment evaluation" and others.

The tutor should preferably start the conversation in the chat or other social network to set the students up for further communication with a friendly conversation. In this case it is necessary both to present organizational issues and to influence the emotions of the recipients - this can be a story of own success, the stories of those who have already completed online training and achieved success, having received the necessary knowledge. This is very motivating, and the impact on emotions captures a positive attitude to communication and steers it in the right direction.

In other words, everything that could happen in a good-natured conversation should occur in online communication with the help of technical means and technologies, namely it is necessary to set up, organize, at certain stages to encourage the student to achieve a positive result in learning; only then the communication goal of successful learning will be achieved in the electronic learning environment.

\section{Conclusions}

Thus, we are once again convinced that properly tuned, successful communication is the key to effective training in the e-learning environment. Otherwise, when there is no clear plan of action, the rules of the game are not outlined, it is unknown which algorithm to follow, a distant student may face disorientation, anxiety and even panic, which will negate all efforts in acquiring the learning material, become an insuperable block, will not allow to complete learning and obtain a positive result.

Consequently, the functions and competencies of both students and educators are changing in the e-learning environment. Communication moves to a different level and starts to be from a peer-to-peer perspective. The tension, bias, and arrogance disappear, though they might have taken place in the traditional educational process that often depended on the mastery and professional skills of a particular educator.

The electronic learning environment requires students to be more self-organized, goaloriented, self-conscious in the learning process, to understand the goals and objectives 
Nadiia Figol. Vasyl Teremko, Iryna Pobidash, Aelita Lytvyn, Tetiana Skorohod, Ruslan Trishchuk.

of their cognitive activity, not to rely on someone or trust to chance, to be inquisitive and passionate.

\section{Bibliographic References}

Boller, S. (2014). eLearning Trends That Will Fizzle, Sizzle, or Simmer in 2014. TiER1 Performance Indy. URL: http://www.bottomlineperformance.com/elearning-trendsfizzled-elearning-trends-sizzle-2014 (10.10.2021).

Carr, L. (2014). 10 predicted e-Learning trends for 2014/15. Lewiscarr. URL: http://lewiscarr.co.uk/2014/05/10-predicted-e-learning-trends-for-201415

(10.10.2021).

Davis, C. (2014). Top Instructional Design Trends and Outlook for 2014. Elearning Industry. URL: http://elearningindustry.com/top-instructional-design-trends-andoutlook-for-2014 (10.10.2021).

Ferriman, J. (2014). The Future of ELearning in 2014. Learndash. URL: http://www.learndash.com/the-future-of-elearning-in-2014 (10.10.2021).

Kukharenko, V.M., Berezens'ka, S.M., Buhaychuk, K.L., Oliynyk, N.YU., Oliynyk, T.O., Rybalko, O.V., Syrotenko, N.H., \& Stolyarevs'ka, A.L. (2016). Theory and practice of blended learning: a monograph. Kharkiv: "Miskdruk", NTU "KhPl", 284 p. URL: http://repository.kpi.kharkov.ua/bitstream/KhPI-

Press/23536/3/Kukharenko_Teoriia_ta_praktyka_2016.pdf

Pappas, C. (2015). The Top eLearning Statistics and Facts for 2015 You Need to Know. Elearning Industry. URL: http://elearningindustry.com/elearning-statistics-andfacts-for-2015 (10.10.2021).

Pinkovetskaia, I., Arbeláez-Campillo, D., Rojas-Bahamón, M., Novikov, S., \& Veas Iniesta, D. (2020). Social values of entrepreneurship in modern countries. Amazonia Investiga, 9(28), 6-13. https://doi.org/10.34069/Al/2020.28.04.1

Polat, E. (2000). Theory and practice of distance education. Materials international conf. "Internet, society, personality. IOL-2000. St. Petersburg.

Rojas-Bahamón, M.J., Aguilar-Cruz, P.J., \& Arbeláez-Campillo, D.F. (2020). Curricular integration as a strategy to strengthen the educational process in public institutions in COVID-19 times. Revista Inclusiones, 7 (num Especial), pp. 233-241.

Sysoeva, S. (2011). Interactive technologies of adult learning: a textbook. Kyiv: VD "EKMO". 324

p.

URL: https://elibrary.kubg.edu.ua/id/eprint/7101/1/\%D0\%A1\%D0\%92\%D0\%86\%D0\%A 2\%D0\%9B\%D0\%90\%D0\%9D\%D0\%90\%20\%D0\%A1\%D0\%98\%D0\%A1\%D0\%9 E\%D0\%84\%D0\%92\%D0\%90\%20\%20\%D0\%86\%D0\%9D\%D0\%A2\%D0\%95\%D 0\%A0\%D0\%90\%D0\%9A\%D0\%A2\%D0\%98\%D0\%92\%D0\%9D\%D0\%86\%20\%D 0\%A2\%D0\%95\%D0\%A5\%D0\%9D\%D0\%9E\%D0\%9B\%D0\%9E\%D0\%93\%D0\% 86\%D0\%87\%20\%20\%D0\%9D\%D0\%90\%D0\%92\%D0\%A7\%D0\%90\%D0\%9D\% D0\%9D\%D0\%AF\%20\%D0\%94\%D0\%9E\%D0\%A0\%D0\%9E\%D0\%A1\%D0\%9B $\%$ D0\%98\%D0\%A5.pdf

Trilling, B. (2007). Toward learning societies and the global challenges for learning with ICT. Australian Educational Computing, 22(1). 